\title{
Compositional Changes of Proteins and Amino Acids in Germinating Coffee Seeds
}

\author{
Milton Massao Shimizu and Paulo Mazzafera* \\ Departamento de Fisiologia Vegetal, Instituto de Biologia, CP 6109, Universidade Estadual de Campinas, \\ 13083-970, Campinas - SP, Brazil
}

\begin{abstract}
Endosperm is the main reserve tissue in coffee seeds. Coffee (Coffea arabica L.) seeds were germinated for six weeks and qualitative and quantitative changes in amino acids and proteins were investigated. The total content of free amino acids were reduced during germination, however, protein content remained constant. SDS-PAGE profiles showed that legumin-like proteins became less stained in the last weeks. Asparagine, glutamic acid, aspartic acid, alanine and lysine were the major free amino acids, although serine and glutamine were also significant. Except for tyrosine, which increased with germination, all other amino acids were reduced. Analysis of the amino acid composition of the total soluble protein showed glutamic acid/glutamine and glycine as the main amino acids. However, other amino acids such as leucine, aspartic acid/asparagine, alanine, lysine, serine were also found in reasonable amounts.
\end{abstract}

Key words: Amino acids; Coffea arabica; endosperm; germination; protein; seeds

\section{INTRODUCTION}

In seeds, proteins accumulate in organelles called protein-bodies, being isolated from uncontrolled proteolysis by proteinases. Upon germination, by action of endo and exoproteinases, small peptides and amino acids generated by cleavage of the storage proteins may remain in the storage tissue or translocated to the developing plant (Callis, 1995). Because they are destined for food use most of the studies concerning protein composition have been carried out in seeds of cereals and legumes, such as wheat, maize, soybean, rice and beans (Payne, 1986). In legumes, seed proteins accumulate in the cotyledon, while endosperm is the main storage organ in cereals. The main storage proteins in legumes are globulins, whereas cereal grains are rich in prolamines and glutelins (Payne, 1986; Müntz, 1998).

Protein mobilization during seed germination is well documented mostly for legumes and cereals (Derbyshire et al., 1976; Callis, 1995; Chiou et al., 1997; Ferreira et al., 1995; Müntz, 1998) although information is also available for other species (Elmore and Paul, 1980; Garcia-Agustin and Primo-Millo, 1989; Garcia-Agustin and
Primo-Millo, 1990; King and Gifford, 1997; Srivastava et al., 1997).

More than $95 \%$ of dry mass of the coffee seed is endosperm tissue and besides galactomanan and lipids, which account approximately for $30 \%$ and $10 \%$, respectively, proteins are present in considerable amount, averaging 10-14\% in Coffea arabica (Clifford, 1985). Amino acids ( 0.5-2\%), caffeine $(\sim 1.2 \%)$ and trigonelline $(\sim 1 \%)$ are other nitrogenous compounds found in the coffee seeds. Although proteins may contribute to the development of the flavour of the coffee beverage, knowledge of their composition is rather scarce. Electrophoretic profiles were studied by a few authors (Centi-Grossi et al., 1969; Amorim and Josephson, 1975; Bade and Stegemann, 1982; Luthe, 1992; Ludwig et al., 1995). In a preliminary study, Centi-Grossi et al. (1969) made an attempt to discriminate species according to the electrophoretic profile of the albumin fraction extracted from coffee seeds. Bade and Stegemann (1982) analyzed proteins from seeds of different coffee species aiming differentiate them according to the profiles obtained with several eletrophoretic systems. Amorim et al. (1975) tried to correlate electrophoretic protein profile of coffee seeds with

* Author for correspondence 
the quality of the beverage. Luthe (1992) analyzed the protein profiles of several dicotyledoneous species, including $C$. arabica. Two main bands were observed in denaturing polyacrylamide gel electrophoresis (SDS-PAGE) and because of their resemblance to the molecular weight of the acidic (a) and basic (b) subunits of legumins, the author classified them as components of legumin-like proteins. Using SDS-PAGE and gel filtration to determine the molecular weight of the native proteins we have observed that each band is probably composed of six subunits, supporting Luthe's suggestion (Bau, Mazzafera and Santoro, unpublished data). Ludwig et al. (1995) fractionated soluble proteins of coffee seeds according to the classification of Osborne (1924) observing the presence of albumin (15\%) and globulin (85\%) type proteins. Two main bands were also observed in SDS-PAGE gels. Recently, Acuña et al. (1999) confirmed 11S proteins as the main storage proteins in coffee seeds.

Most studies on coffee germination have dealt with preservation of the seed viability (Ellis et al., 1990) and to our knowledge, only two followed compositional changes during the process, in which the biological role of caffeine was investigated in germinating coffee seeds (Friedman and Waller, 1983; Baumann and Gabriel, 1984). In this paper we have examined the quantitative and qualitative changes of proteins and amino acids during the germination of coffee seeds.

\section{MATERIALS AND METHODS}

Plant material and germination: Seeds of $C$. arabica cv. Mundo Novo were obtained from mature fruits from a tree growing locally. The fruits were manually depulped and after $48 \mathrm{~h}$ the seeds were rubbed against each other and rinsed with water several times until the mucilage adhered to the endocarp was removed. Then they were left to dry at room temperature $\left(25-28^{\circ} \mathrm{C}\right)$ to a moisture content of $12 \%$ and the endocarp manually removed. Only seeds flat on one side and curved on the other were kept. Seeds displaying any visible damage were discarded. Germination of these seeds in the conditions described below was $100 \%$.

Seeds positioned with the flat side facing down were germinated in Petri dishes with water soaked filter paper at $20^{\circ} \mathrm{C}$ and in the dark. Every second day, the seeds were transferred to new Petri dishes and seeds showing any contamination by microorganisms were removed.

Analyses: During six weeks 30 seeds were sampled each time from the Petri dishes and used for the analysis. Dry seeds were also analyzed. After drying at room temperature $\left(25-28^{\circ} \mathrm{C}\right)$ for a week, reaching on average a moisture of $10 \%$, the seeds were sliced into thin layers, transferred to Erlenmeyer flasks containing $100 \mathrm{ml}$ hexane and defatted at room temperature for two days in a rotatory shaker. The hexane was removed by leaving the seeds for several hours in a fume hood. Then they were finely ground to a powder in a ball mill.

Proteins were extracted in a mortar with a pestle $\left(4^{\circ} \mathrm{C}\right)$ with $100 \mathrm{mM}$ sodium borate buffer, $\mathrm{pH} 8,0$, containing $50 \mathrm{mM}$ diethyldithiocarbamic acid, 50 $\mathrm{mM}$ ethylenediaminetetraacetic acid, $0,3 \mathrm{M}$ sodium chloride, $2 \%$ ascorbic acid, in a proportion of 200 $\mathrm{mg} / 3 \mathrm{ml}$. The extract was centrifuged and the pellet re-extracted with the same buffer. The supernatants were pooled and the protein concentration determined using a ready-to-use BioRad reagent (Bradford, 1976). Electrophoretic protein profiles were obtained by subjecting reduced proteins to discontinuous SDS-PAGE (Laemmli, 1970), with $17 \%$ of acrylamide in the main gel. Proteins were stained with Coomassie Brilliant Blue R.

For the determination of the amino acid composition of the soluble proteins of the coffee seeds, powder of ungerminated seeds was extracted three times with borate buffer, as described above, and precipitated with $\left(\mathrm{NH}_{4}\right)_{2} \mathrm{SO}_{4} \quad(20-80 \%$ saturation). The proteins were dialyzed against deionized water $\left(4^{\circ} \mathrm{C}, 24 \mathrm{~h}\right.$ and 4 changes), and hydrolyzed with $6 \mathrm{~N} \mathrm{HCl}$ at $105^{\circ} \mathrm{C}$ for $24 \mathrm{~h}$. The extract was dried, solubilized in a small volume of deionized water, filtered $(0.2 \mathrm{~mm})$ and used for the determination of the amino acid composition by high-performance liquid chromatography (HPLC) with fluorescence detection (Jarret et al., 1986). Free amino acids were extracted from the seed powder $\quad(50 \mathrm{mg} / 2 \mathrm{ml})$ with methanol-chloroform-water - 12:5:3, v/v/v (Bielesk and Turner, 1966). The extracts were left one week at $4^{\circ} \mathrm{C}$, with occasional agitation. Then $0.5 \mathrm{ml}$ chloroform and $0.75 \mathrm{ml}$ of distilled water were added and the extract agitated vigorously. After quick centrifugation for separation of phases, 
aliquots were taken from the upper methanolic-aqueous phase, dried with a N2 stream, solubilized in deionized water, filtered in $0.2 \mu \mathrm{m}$ filters and used for quantitative (Cocking and Yemm, 1954) and qualitative determinations in HPLC (Jarret et al., 1986).

Except for the determination of amino acid composition of coffee proteins, for which two replicates were made, all other data presented are means of four replicates.

\section{RESULTS}

Radicle protrusion started after two weeks the seeds were put to germinate in Petri dishes. At the end of the experiments the roots were on average two centimeters long. They were separated and not considered for analysis. Since germination was carried out at $20^{\circ} \mathrm{C}$, in the last sampling the cotyledonary leaves were still poorly developed inside of the seeds. Therefore, at this stage, the main tissue was still endosperm. Optimum temperature for coffee seed germination has been found to be between $25-30^{\circ} \mathrm{C}$ (Baumann and Gabriel, 1984; Ellis et al., 1990).

During the first two weeks of germination, the total amino acids content was reduced in the germinating coffee seeds (Table 1). During the $3^{\text {rd }}$ and $4^{\text {th }}$ weeks, the levels were restored to those of ungerminated seeds, followed by a marked decrease during the two last weeks. The total protein content followed the same pattern of the amino acids until the $4^{\text {th }}$ week. However, in the $5^{\text {th }}$ and $6^{\text {th }}$ weeks, the content was increased (Table 1).

Qualitative analysis of ungerminated seeds showed, in descending order, that asparagine, glutamic acid, aspartic acid, alanine and lysine were the major free amino acids (Table 2). Serine and glutamine were also found in considerable amounts. These amino acids represented approximately $80 \%$ of the total amino acids detected during the whole sampling period. Similar to the colorimetric determinations, the sum of the amino acids detected by HPLC showed a decrease with germination, however, in this case, this was observed since the first week. Tyrosine and glutamine were exceptions, since there was an increase of the first, while the second showed at the $6^{\text {th }}$ week similar content of ungerminated seeds.

Fig. 1A shows an electrophoretic profile of proteins extracted from ungerminated seeds deffated with hexane in a Soxhlet apparatus for $24 \mathrm{~h}$. Two main bands corresponding to 23.9 and $35.7 \mathrm{kDa}$ predominated. These proteins are also seen in Fig. 1B, which shows electrophoretic profiles of germinating seeds, however, the gel lacks definition probably because seeds in this case were deffated with hexane at room temperature and not in a Soxhlet apparatus. This was done because these samples were also used for amino acids extraction and heating could change their composition (Arnold and Ludwig, 1996).

Table 1 - Total free amino acid and soluble protein contents of coffee seeds during germination.

\begin{tabular}{ccccccc}
\hline \multicolumn{7}{c}{ Germination time (weeks) ${ }^{\mathrm{a}}$} \\
0 & 1 & 2 & 3 & 4 & 5 & 6 \\
\hline \multicolumn{7}{c}{ Amino Acids (mg/g) } \\
$(0.5)$ & 8.0 & 7.9 & 9.7 & 8.8 & 6.2 & 5.4 \\
\multicolumn{10}{c}{ Proteins (mg/g) } & $(0.1)$ & $(0.2)$ & $(0.1)$ & $(0.5)$ & $(0.1)$ & $(0.5)$ \\
65.9 & 65.1 & 63.0 & 65.1 & 62.6 & 66.1 & 65.5 \\
$(0.9)$ & $(1.8)$ & $(1.0)$ & $(2.4)$ & $(1.6)$ & $(3.6)$ & $(1.2)$ \\
7
\end{tabular}

${ }^{\mathrm{a}}$ Data are means of four replicates. Numbers in parenthesis are standard errors.

Table 2 - Free amino acids variations during germination of coffee seeds.

\begin{tabular}{lccccccc}
\hline Amino & \multicolumn{7}{c}{ Germination time $(\text { weeks })^{\mathrm{a}}$} \\
Acid & 0 & 1 & 2 & 3 & 4 & 5 & 6 \\
\hline Asp & 1.5 & 2.2 & 1.4 & 2.0 & 1.9 & 0.9 & 0.6 \\
Glu & 2.0 & 1.2 & 1.1 & 1.0 & 1.4 & 0.9 & 0.4 \\
Asn & 2.3 & 1.6 & 1.4 & 1.3 & 1.6 & 0.4 & 0.2 \\
Ser & 0.7 & 0.6 & 0.7 & 0.7 & 0.9 & 0.6 & 0.3 \\
Gln & 0.6 & 0.3 & 0.4 & 0.2 & 0.6 & 0.5 & 0.4 \\
His & 0.2 & 0.1 & 0.1 & 0.1 & 0.2 & 0.1 & 0.1 \\
Gly & 0.1 & 0.1 & 0.1 & 0.1 & 0.1 & 0.1 & 0.1 \\
Thr & 0.1 & 0.1 & 0.2 & 0.1 & 0.1 & 0.1 & 0.1 \\
Arg & 0.3 & 0.2 & 0.2 & 0.3 & 0.3 & 0.4 & 0.1 \\
Ala & 1.1 & 0.8 & 1.1 & 1.2 & 0.8 & 0.5 & 0.4 \\
Tyr & 0.4 & 0.6 & 0.9 & 0.8 & 0.6 & 0.5 & 0.5 \\
Met & 0.3 & 0.2 & 0.2 & 0.2 & 0.2 & 0.2 & 0.1 \\
Val & 0.2 & 0.2 & 0.3 & 0.3 & 0.2 & 0.2 & 0.1 \\
Phe & 0.5 & 0.3 & 0.3 & 0.2 & 0.2 & 0.1 & 0.1 \\
Iso & 0.2 & 0.2 & 0.2 & 0.2 & 0.1 & 0.1 & 0.1 \\
Leu & 0.2 & 0.2 & 0.2 & 0.2 & 0.1 & 0.1 & 0.1 \\
Lys & 1.1 & 0.6 & 0.5 & 0.5 & 0.6 & 0.6 & 0.5
\end{tabular}


$\begin{array}{llllllll}\text { Total } & 12 & 9.5 & 9.2 & 9.3 & 9.9 & 6.1 & 4.0\end{array}$

${ }^{\mathrm{a}}$ Means of four replicates. Standard errors were not higher than $20 \%$ of the mean values.

Although total protein content showed little variation (Table 1), electrophoretic profile showed significant alterations (Fig. 1B). During the germination, the 23.9 and $35.7 \mathrm{kDa}$ bands decreased in intensity (indicated by arrows in lane 0) and proteins with low molecular weights were more stained or started to be visible only at later stages of germination. However, the most noticeable observation in the protein profile was a strongly stained band of approximately $30.5 \mathrm{kDa}$ observed at the $4^{\text {th }}$ week (indicated by arrow). This band could be already seen in extracts from the $3^{\text {th }}$ week, however, at week $5^{\text {th }}$ it became very faint. Since this band was observed in all four replicates, contamination by microorganisms was ruled out as a possibility.

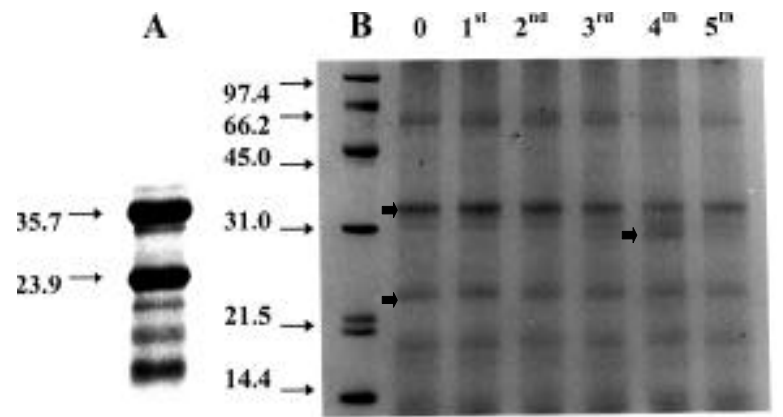

Figure 1 - Electrophoretic profile of proteins extracted from (A) ungerminated seeds deffated with hexane in a Soxhlet apparatus for $24 \mathrm{~h}$ and (B) germinating seeds deffated with hexane at room temperature. Numbers at left indicate molecular markers $(\mathrm{kDa})$.

Glutamic acid/glutamine and glycine were the major amino acids of the coffee seed proteins (Fig. 2). However, amino acids such as leucine, aspartic acid/asparagine, alanine, lysine, serine were also found in reasonable amounts. Compared with the most abundant free amino acids and week 0 (Table 2 ), only glycine and leucine were not common.

\section{DISCUSSION}

Proteins constitute the major nitrogen reserve in the coffee seeds, representing approximately $60 \%$ of the total nitrogen (Clifford, 1985). For other nitrogenous compounds, such as caffeine, there is no proof of its significance as a nitrogen storage molecule in coffee (Baumann and Gabriel, 1984; Suzuki and Waller, 1986; Mazzafera, 1990).

SDS-PAGE profile of proteins of coffee seeds showed the two main bands previously observed by other authors (Bade and Stegemann, 1982; Luthe, 1992; Ludwig et al., 1995; Acuña et al., 1999). During germination there was a decrease of these bands indicating that they were hydrolyzed. However, total protein content, as indicated by the colorimetric estimates did not show significant alteration. This may be explained by the appearance of small polypeptides, as degradation products, as well as by the synthesis of other proteins. In their study on the physiological role of caffeine, Baumann and Gabriel (1984) observed reduction of proteins in the coffee seeds. However, as these authors presented the data per seed fresh weight, they are not comparable with those presented here.

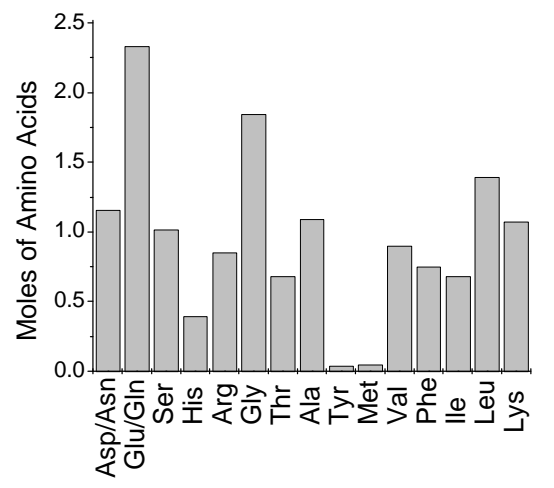

Figure 2 - Amino acid composition of total soluble coffee seed proteins.

The amino acid composition of the total protein fraction of ungerminated coffee seeds obtained in this study is in agreement with a previous study (Ludwig et al., 1995). The same was observed for free amino acids (Clifford, 1985; Arnold and Ludwig, 1996), although the lysine contents determined here were a little higher. However, depending on the seed origin, lysine content may vary significantly (Arnold and Ludwig, 1996).

Seed storage proteins are rich in asparagine and glutamine, which have higher proportion of nitrogen in the molecule (Payne, 1986). Unfortunately, the acid-hydrolysis used for the 
determination of the amino acid composition of the proteins of coffee seeds did not allow differentiation between these amino acids and their acidic forms, since glutamine is converted into glutamate. The composition of the total seed protein showed the predominance of glutamate, representing $16 \%$ of the amino acids. Assuming that most of the glutamate detected was in fact glutamine, one might expect increase of free glutamine during germination. However, for this amino acid as well as for asparagine it was observed a decrease for the whole germination period. In spite of that, it is interesting to observe that asparagine was the major free amino acid in ungerminated seeds and that there was an increase of aspartate in the first four weeks. As asparagine and glutamine are the main amino acids transported in coffee seedlings (Mazzafera and Gonçalves, 1999), it is probable that glutamine generated by hydrolysis of storage proteins is either translocated to the seedling or converted to asparagine, by nitrogen transfer to aspartate. Other possibility is that these amino acids are used for the synthesis of new proteins.

Endosperm is the storage tissue in coffee seeds. In mature seeds a small embryo is situated near one end of the curved side of the seed. Upon germination, the cotyledonary leaves develop inside of the seed, occupying the space released by the inner part of endosperm as the reserves are hydrolyzed. Since in viable seeds there is a close contact between endosperm and embryo cells (Dentan and Illy, 1985; Begnami, 1998), it is expected that nutrients migrate from one to the other. Under optimal germinating conditions, the cotyledonary leaves expand out of the endosperm after 7-9 weeks, when the endosperm reserves are almost entirely exhausted. At this stage, the cotyledonary leaves are almost fully developed in size, indicating that their growth inside of the seed was supported by the endosperm reserves. Released cotyledons are green and become a nutrient source for the developing leaves.

The majority of the studies on protein mobilization in germinating seeds was carried out in legumes and cereals (Derbyshire et al., 1976; Bewley and Black, 1994; Callis, 1995). In legume seeds, which have cotyledons as the main storage tissue, following protein hydrolysis, it is observed an increase of the amino acid contents, which in turn are transported to the growing seedling. In many species the endosperm grows rapidly in the early stages of seed formation, becoming senescent before maturity, since it is used as food source during seed development (Payne, 1986). In cereals, as well as in coffee, endosperm continues to develop and becomes the major reserve tissue of the seed. However, differently of coffee, in cereals the endosperm reserves are hydrolyzed very rapidly during germination in order to guarantee seedling establishment.

Depending on the plant species the embryo is not necessary for the protein breakdown since some studies showed proteolytic activity in excised endosperm seeds (Harvey and Oaks, 1974; Adams and Novellie, 1975). This indicates that proteinases synthesized during seed maturation are stored and become active on germination. In some cases, activation follows degradation of proteinase inhibitors (Callis, 1995). However, for many plant species proteinases are de novo synthesized during germination (Rogers et al., 1985; Mitsuhashi and Minamikawa, 1989; Cervantes et al., 1994). Evidence from angiosperm and gymnosperm species support this as a general mechanism for most of the plant species (Shutov and Vaintraub, 1987; Callis, 1995).

Apparently, manans and lipids in the coffee endosperm are hydrolyzed by enzymes excreted by the cotyledons, since mobilization of these reserves seems to start from the embryo positioned in one side of the seed (Ouguerram, 1989). Ultrastructural analysis of dry coffee seeds showed that the endosperm and cotyledons are rich in protein bodies (Dentan and Illy, 1985; Begnami, 1998). However it is not known if during germination proteinases are released by the embryo or if they are already present in the endosperm cells. Questions like this and others regarding proteinases action are under investigation in our laboratory in order to know how proteins are mobilized during the germination of coffee seed.

\section{ACKNOWLEDGMENTS}

M.M.S. thanks CNPq for a Master's thesis fellowship and P.M. for a research fellowship. This work was partially supported by FAPESP-São Paulo (Grant 97/01926-0). 


\section{RESUMO}

Endosperma é o principal tecido de reserva em sementes de café. Sementes de café (Coffea arabica L.) foram germinadas por seis semanas e as alterações qualitativas e quantitativas de aminoácidos e proteínas foram investigadas. O conteúdo total de aminoácidos livres reduziu durante a germinação, no entanto, o conteúdo de proteínas permaneceu constante. Perfis eletroforéticos de proteínas em SDS-PAGE mostraram que proteínas do tipo legumina foram menos coradas nas últimas semanas. Asparagina, ácido glutâmico, ácido aspártico, alanina e lisina foram os principais aminoácidos, apesar de que serina e glutamina também estavam presentes em quantidades significativas. Exceto tirosina, a qual aumentou durante a germinação, todos os outros aminoácidos tiveram redução em sua concentração. A análise aminoacídica da fração de proteína solúvel total mostrou que ácido glutâmico/glutamina e glicina eram os principais aminoácidos presentes. No entanto, outros aminoácidos, tais como leucina, ácido aspártico/asparagina, alanina, lisina e serina, também foram encontrados em quantidades expressivas.

\section{REFERENCES}

Acuña, R.; Bassüner, R.; Beilinson, V.; Cortina, H.; Cadena-Gómez, G.; Montes, V. \& Nielsen, N.C. (1999). Coffee seeds contains $11 \mathrm{~S}$ storage proteins. Physiol. Plant., 105, 122-131.

Adams, C.A. \& Novellie, L. (1975). Acid hydrolases and autolytic properties of protein bodies and spherosomes isolated from ungerminated seeds of Sorghum bicolor (Linn.) Moench. Plant Physiol., 55, 7-11.

Amorim, H.V. \& Josephson, R.V. (1975). Water-soluble protein- and non-protein components of Brazilian green coffee beans. J. Food Sci., 40, 1179-1185.

Arnold, U. \& Ludwig, E. (1996). Analysis of free amino acids in green coffee beans II. Changes of the amino acid content in arabica coffees in connection with post-harvest model treatment. Z.Lebensm. Unters. Forsch., 203, 379-384.

Bade, H. \& Stegemann, H. (1982). Protein patterns of coffee beans. Characterization by one- and two-dimensional electrophoresis. J. Agron. Crop Sci., 151, 89-98.

Baumann, T.W. \& Gabriel, H. (1984). Metabolism and excretion of caffeine during germination of Coffea arabica L. Plant Cell Physiol., 25, 1431-1436.
Begnami, C.N. (1998). Alterações estruturais, ultraestruturais e bioquímicas durante a perda de viabilidade em sementes de Coffea arabica cv. Catuaí Vermelho. Ph.D. Thesis, State University of Campinas - Brazil.

Bewley, J.D. \& Black, M. (1994). Seeds: Physiology of development and germination. ( $2^{\text {nd }}$ edition) New York, USA, Plenum Press.

Bielesk, R.L. \& Turner, N.A. (1966). Separation and estimation of amino acids in crude plant extracts by thin layer electrophoresis and chromatography. Anal Biochem., 17, 278-282.

Bradford, M.N. (1976). A rapid and sensitive method for the quantitation of microgram quantities of protein utilizing the principle of protein-dye binding. Anal. Biochem., 72, 248-254.

Callis, J. (1995). Regulation of protein degradation. Plant Cell., 7, 845-857.

Centi-Grossi, M.; Tassi-Micco, C. \& Silano, V. (1969). Albumin fractionation of green coffee seed varieties by acrylamide gel-electrophoresis. Phytochemistry, 8, 1749-1751.

Cervantes, E.; Rodriguez, A. \& Nicolás, G. (1994). Ethylene regulates the expression of a cysteine proteinase gene during germination of chickpea (Cicer arietinum L.). Plant Mol. Biol., 25, 207-215.

Chiou, R.Y.-Y.; Ku, K.-L. \& Chen, W.-L. (1997). Compositional characterization of peanut kernels after subjection to various germination times. J. Agric. Food Chem., 45, 3060-3064.

Clifford, M.N. (1985). Chemical and physical aspects of green coffee and coffee products. In: Coffee: Botany, Biochemistry and Production of Beans and Beverage. eds M.N. Clifford, M.N., K.C. Willson. AVI Publishing Company, Inc., Westport, Connecticut, USA, pp. 305-374.

Cocking, E.C. \& Yemm, E.W. (1954). Estimation of amino acids by ninhidrin. Biochem. J., 58, xii-xiii.

Dentan, E. \& Illy, A. (1985). Étude microscopique de grains de café matures, immatures et immatures fermentés arabica Santos. Proceedings of the XI International Scientific Colloquium on Coffee, Lomé, Togo, pp 341-350.

Derbyshire, E.; Wright, D.J. \& Boulter, D. (1976). Legumin and vicilin, storage proteins of legumes seeds. Phytochemistry, 15, 3-24.

Ellis, R.H.; Hong, T.D. \& Roberts, E.H. (1990). An intermediate category of seed storage behaviour? I. Coffee. J. Exp. Bot., 41, 1167-1174.

Elmore, C.D. \& Paul, R.N. (1980). Light and nitrogen affect storage protein mobilization in germinating cottonseed. Crop Sci., 20, 435-443.

Ferreira, R.B.; Melo, T.S. \& Teixeira, A.N. (1995). Catabolism of the seed storage proteins from Lupinus albus: fate of globulins during germination and seedling growth. Austr. J. Plant Physiol., 22, 373-381. 
Friedman, J. \& Waller, G.R. (1983). Caffeine hazards and their prevention in germinating seeds of coffee (Coffea arabica L.). J. Chem. Ecol., 9, 1099-1106.

Garcia-Agustin, P. \& Primo-Millo, E. (1989). Ultrastructural and biochemical changes in cotyledon reserve tissues during germination of citrus seeds. $J$. Exp. Bot., 40, 383-390.

Garcia-Agustin, P. \& Primo-Millo, E. (1990). Changes in some nitrogenous components during the germination of citrus seeds. Scient. Horticult., 43, 69-81.

Harvey, B.M.R. \& Oaks, A. (1974). The hydrolysis of endosperm protein in Zea mays. Plant Physiol., $\mathbf{5 3}, 453-457$.

Jarret, H.W.; Coosky, K.D.; Ellis, B. \& Anderson, J.M. (1986). The separation of $o$-phtalaldehyde derivatives of amino acids by reversed-phase chromatography on octylsilica column. Anal. Biochem., 153, 189-198.

King, J.E. \& Gifford, D.J. (1997). Amino acid utilization in seeds of loblolly pine during germination and early seedling growth. I. aarginine and arginase activity. Plant Physiol., 113, 1125-1135.

Laemmli, U.K. (1970). Cleavage of structural protein during the assembly of head of bacteriophage $T_{4}$. Nature, 227, 680-684.

Ludwig, E.; Raczek, N.N. \& Kurrock, T. (1995). Contribution to composition and reactivity of coffee protein. Proceedings of the XVI International Scientific Colloquium on Coffee, Kyoto, Japan, pp 359-365.

Luthe, D.S. (1992). Electrophoretic analysis of seed proteins in the Dycotiledoneae. Plant Mol. Biol. Rep., 10, 254-262.

Mazzafera, P. (1990). Estudo sobre o papel da cafeína em plântulas de café (Coffea arabica L.). Rev. bras. Bot., 13, 97-102.

Mazzafera, P. \& Gonçalves, K.V. (1998). Nitrogen compounds in the xylem sap of coffee. Phytochemistry, 50, 383-386.

Mitsuhashi, W. \& Minamikawa, T. (1989). Synthesis and posttranslational activation of sulfhydril-endopeptidase in cotyledons of germinating Vigna mungo seeds. Plant Physiol., 89, 274-279.

Müntz, K. (1998). Deposition of storage proteins. Plant Mol. Biol., 38, 77-99.
Osborne, T.B. (1924). The vegetable proteins. Monographs in Biochemistry. London, UK, Longmans, Green and Co.

Ouguerram, A. (1989). Formation et digestion desparois cellulaires de réserves à mannanes du café (Coffea arabica L.). Ann. Scien. Natur. - Botanique., 10, 111-133.

Payne, P.I. (1986). Endosperm proteins. In: A Genetic Approach to Plant Biochemistry. eds. A.D. Blonstein, P.J. King. Springer-Verlag, New York, USA, pp 205-231.

Rogers, J.C.; Dean, D. \& Heck, G.R. (1985). Aleurain: a barley thiol protease closely related to mammalian cathepsin H. Proc. Natl. Acad. Sci. USA., 82, 6512-6516.

Shutov, A.D. \& Vaintraub, I.A. (1987). Degradation of storage proteins in germinating seeds. Phytochemistry, 26, 1557-1566.

Srivastava, N.; Prakash, D. \& Behl, H.M. (1997). Biochemical contents, their variation and changes in free amino acids during seed germination in Terminalia arjuna. Int. J. Food Sci. Nutr., 48, 215-219.

Suzuki, T. \& waller, G.R. (1986). Total nitrogen and purine allaoids in the tea plant throughout the year. $J$. Sci. Food Agric., 37,862-866. 